\title{
The Fusion of Ideas: An Interview with Margaret Walker Alexander
}

$\mathrm{M}$ argaret Walker is the prize-winning author of For My People, the first collection by an African American writer to win a national award. Published by Yale University in 1942, the volume celebrated its fifty-year anniversary as Walker herself turned 77 in 1992. This interview took place in Jackson, Mississippi, on July 14, 1992, in the home of Margaret Walker who, in addition to being a poet, is a novelist, biographer, and critical essayist. Informed by Walker's decidedly historicist approach to literature, the interview covers Walker's lengthy career, politics, and current projects.

Graham: I'd like to talk about the book This Is My Century as a representative text.

Alexander: From my early adolescence, I've been dealing with the meaning of the century. I was born when it was barely fifteen years old, and now we have less than ten years left in this century. So the body of my work - whether it's Jubilee, For My People, This Is My Century, or Richard Wright-springs from my interest in a historical point of view that is central to the development of black people as we approach the 21st century. That is my theme, and I have tried to express it, both in prose and poetry. I feel that, if I've learned anything about this country and century, I've expressed it already in the books I've written. There are a few more I'd like to do, and that same theme is there. For example, I think that, when you look at the Civil Rights Movement and remember the violence of the 1960s and the legislation that came out of it, we make a mistake to think that the protest movement of the ' $60 \mathrm{~s}$ was an isolated decade in itself. Protest, for black people in this country, is more than a century old. It began right after slavery, but particularly toward the end of the 19th century, and from the beginning of the 20th century with Du Bois and the NAACP, and the Urban League, in the first ten years of this century. The whole issue for black people was protesting the treatment received from the government and the question of whether we had equal rights. When I was born, we were in the very beginning of World War I. This country had not entered into it yet. And, basically, what we had at the beginning of World War I was reflected again in World War II.

Graham: What is it that you're saying we saw in both wars?

Alexander: Well, the problems that World War I stirred up and left started World War II. And we can go further than that. During the 20th century, this country has engaged in war on four
Maryemma Graham, an associate professor of English at Northeastem University, is director of the History of Black Writing Project and co-editor of the Richard Wright Newsletter. Professor Graham wishes to thank Sheri Divers for her assistance in transcribing this interview. 
continents other than North America. The century really began with the Spanish-American War, and we were dealing with nations south of the border. I remember reading in the newspapers almost every day when I was a high school student about a new revolution taking place south of the border. We went through some fifteen years of that. I don't recall the Russian Revolution, because I was only about two years old, but it was a big and important issue of the 20th century. And then World War I was fought for control of land, people, and money. Telling the folk that it was a war fought for the benefit of democracy was a slogan. This country banked the raw. They not only sent people to France to die over there-they loaned them money. And when the war was over, everybody owed this country. Some of them paid it, and some didn't. And as a result of fifteen years of bad management, the country entered the Depression.

If you look at the period in America after each world war and each foreign war, you will discover five issues: the health of the people, the education of the people, the economy, the political ideas that develop the world's economic state, and the whole nature of the state vs. the church. The issues that we face everyday in Congress are issues that have come out of these five things.

Every time we have a war, we have to change the economy. My mother said that, before World War I, you could go with a dollar and buy groceries for a family. You could take 25 cents and buy meat. Nickels and dimes counted. But, after World War I, pennies, nickels, dimes, and quarters did not count anymore. I can recall that, prior to World War II (and I mention this in the poem "Youth and Age" in This Is My Century), I bought three pounds of onions for a dime; look at how much it costs to buy three pounds of onions today. You could buy a loaf of bread for a nickel or a dime. When I was a child you could buy a pint or quart of milk for 11 cents. You see the difference in the economies.

I was married during World War II, and when my husband and I came to Jackson, I could buy a week's worth of groceries for $\$ 15$. When I moved into my present house after the Korean War, $\$ 100$ would buy two weeks' groceries. When I came back from Iowa, I couldn't expect my grocery bill for the same family of six to be $\$ 25$ or $\$ 35$ anymore-it had moved up, until it got to the point where I couldn't expect to get a week's groceries for less than $\$ 100$. It hasn't gotten any less than that since.

Graham: Would you say that This Is My Century is a protest against or in response to conditions that black people have faced throughout this century?

Alexander: Well, for black people, the 20th century has been a century of protest. And in all my work I look first at the historical perspective. I'm always looking back in order to understand what's happening today, and what may happen tomorrow. If we understand yesterday, then we know what's happening today, and we can reasonably predict what will happen tomorrow.

Graham: There's a general view, which a lot of us in literature are trying to fight now, that protest is a dated mode of expression, and that it does not good literature make, or does not good sustained art make. This is a real problem in terms of arguing the motivation for or inspiration behind black writing. How would you speak to this issue?

Alexander: Consider protest in terms of politics and policy. When I first realized that we live by protest and not just propaganda, it was way back in the 1930s. I lived through the march 
from the Depression in this country and saw a liberal administration under Roosevelt. I saw that. And I believe the television political correspondent who says, "This conservative country has thrived and lived on liberalism, fighting it all the time but living with it." The things that happened during the 1930s and the Civil Rights Movement have been the gleams of light that poor black people have looked to in terms of social and liberal legislation.

I believe that every issue in the country now boils down to race. Whether it's education, unemployment and labor, health, politics, religion, or the family-all the social institutions are now affected by this country's attitude toward race. And to protest the gradual encroachment of the conservative and fascist youths behooves the liberal.

It's now that we have administrations under men like Nixon, Reagan, and Bush that we are told that those of us who believed in Roosevelt, Johnson, Truman, Kennedy, and Carter were dirty liberals. Every 20thcentury social movement in this country emerged from liberal thinking, and the conservatives who are standing up claiming everything have carried us into a morass. There is no way we can look ahead and see the future of this country without realizing that we are on the bottom in terms of economic development. Things like housing, education, the professions, and the arts do not receive funding. Instead, we must spend our taxpayers' money on arms, military assemblages, and in support of foreign nations like Israel and South Africa? I can't believe that we are looking toward a healthy future.

Graham: And you don't believe that the writer's responsibility in relation to all that you have said has changed in terms of giving voice?
Alexander: Well, it hasn't changed for me, and it hasn't changed for the people I've known and worked with through all these years. It has always been my understanding from my school days that the writer's responsibility is the same as that of the social scientist or philosopher: to be like God and show the way. And certainly this consists of telling the people... not only analyzing what is happening to us everyday, but showing the way we must go for a better life, a healthy economy, better education for our children, physical health and fitness. These are the things that we should think about.

My father used to say that money has no intrinsic value but to a miser. You could only do three things with money: save it, spend it, or give it away. If you saved everything you had, you were a miser; if you spent everything you had, you were a spendthrift; and if you gave everything away, you were a fool. And so you were supposed to do something of each of these with any dollar you had, and then you should spend money for the conservation of life's highest values. You have to spend money for shelter, food if you want to live, and education. You should also spend money for recreation and health. Then you should save some for a rainy day. I was raised that way-to believe that money itself has no intrinsic value, but what you do with money leads to life's highest values.

Graham: Let's look at the books you have coming out in the next year or two. Why are these books important for you to do?

Alexander: I expect to have at least three books published next year-two are in the publishers' hands-and I'm waiting on the fourth. The first book that is already in production and should be out in January of 1993 is the book about Sister Thea Bowman's life. It's a deeply religious and spiritual 
book called God Touched My Life, 1 and that is what Thea Bowman is saying. I believe it is an interesting book because she talks about life in Mississippi as a black girl and what it was like in Canton going to the public schools before the Catholic sisters came and started an educational institution. She talks about the Civil Rights days when Martin Luther King came through Canton, and life in Washington at the height of the 1960s and early '70s when she was doing graduate work at the Catholic University. Here is a woman who comes from a certain background-her father was a doctor and her mother a school teacher. She lived in a deeply earthy, black religious culture, surrounded by churches of every denomination. A Southerner in part, she is transported to a very white, rich, Northern, cold culture. When she went to the convent to be a nun, she said there were about three black people present, and they were strangers. Everybody was white, the climate was cold, and it was very hard for her. Then she contracted tuberculosis. How she overcame so many things, how she lived for ten years or more with cancer, what happened to her parents, and how she went around the world preaching the gospel-that's the story of that book. I think it's a very inspiring story.

I have another book that's not quite in production stage, but it ought to be by the fall of the year. It's in the process of being read by a number of readers. It's on Jesse Jackson and his relationship to black politics in Mississippi and the nation. ${ }^{2}$ We don't see Jesse as the black messiah, or that hustler from Chicago, but we do see him as a very magnetic political leader of black people from 1983 to 1988.

Graham: So this book concentrates on that period of his life?
Alexander: On those two presidential campaigns. It will include his speeches announcing his intention to run for the presidency and the ones he gave at the conventions. Then we have interviews with some of the key leaders in Mississippi black politics. We also focus on the chairman of the Democratic party and how he has come up through the ranks of this political party, working with the NAACP, and Senator Eastland. We have Aaron Henry, who has been the chairman of the state NAACP for 25 years. Leslie McLemore has an article from his book on Fannie Lou Hamer, whom he sees as a catalytic agent for social change-a very important woman. And then we have Senator Henry Kirksey, whom we call a political gasline. We also deal with what happened in Mississippi from 1964 to 1984.

Jesse Jackson says his interest in politics began with the challenge to the Democratic Party by the Mississippi Freedom Democratic Party (MFDP) in 1964. Fannie Lou Hamer was there; we have a list of the people who were there. He says that he realized the Voting Rights Act of 1965 was the beginning of a need for voter registration, and we know that Jesse's actions in several cities caused us to get black mayors in Chicago and in New York, and had something to do with a black mayor's being elected in Washington. We see Jesse Jackson in Mississippi with what he called the Southern Crusade. It began in Memphis and came to Tunica, Mississippi, where there was a ditch in people's neighborhoods where they were suffering.

Graham: Sugar Ditch?

Alexander: Yes. Then we see the people who were around Jesse and followed him through Mississippi, were the lieutenants of his first campaign. People like Louis Armstrong have ad- 
vanced to the city council in local politics. Leslie McLemore has run for Congress and several other offices, although he's not been successful in being elected. He is a political scientist and one of the editors of the book. Mary Dellareese Coleman has provided major assistance.

We think that the book is important, not just for a look at Jesse Jackson as a national political leader of black people and an international presence, but to show what it has taken in redistricting - getting rid of gerrymandering, voting and challenging the status quo-to change politics in America, and to work for the rights of black people. What Jesse Jackson is all about was not just to be the President of the United States, but to create social change, and that's what he did.

Graham: But isn't there an issue that one has to consider in terms of the relationship between the MFDP, which was in essence outside of the mainstream two-party system challenging that system, and Jesse, who became a nominee for one of the parties?

Alexander: He really didn't become a nominee until later. He was never nominated, remember, although he came close to it.

Graham: What I'm saying is that the MFDP seems to have had aims that were more radical and revolutionary

...

Alexander: That's an interesting point that you're raising, because as I look back to the 1930s and remember a decade of what they called social change and radicalism in this country, I remember the CIO was a hallmark in the $1930 \mathrm{~s}$. Black laborers were not in the unions; they were scabs, because the AFL would not admit black people to the unions, and a man like John $L$. Lewis came south with the automobile workers and the miners and organized unions from Philadelphia to Birmingham, Alabama, in the '30s.
And that changed the picture of American labor. Now in the Republican counter-revolution, we have seen how the aim of the Republicans is to break the back of the unions. Why? Because we are the bulwark of American labor and the economy, and when the unions are broken and you have no backbone for the economy, what happens? You're looking at unemployment, homelessness, and chaos.

Graham: I was just trying to get at the MFDP model.

Alexander: The MFDP was not purely a moderate thing. It was a revolutionary movement that was outside of the usual political strategy.

Graham: Yes, it was. There's a question I've always wanted to ask, and I think it's a good time. In your poetry, you celebrate the average man and woman in the "For My People" tradition, whereas in the books that you've written-biographies, histories-you celebrate individual figures that are prominent, who had some really significant roles in terms of leadership. There's an interesting kind of contrast there between the representation of the masses of people and those in leadership positions. Will you talk a little bit about that?

Alexander: That's not what I'm after. What I have always tried to do in my poetry-even before I was conscious about revolution, freedom, social gains, or any of that-was to look at the Southern world around me, to appraise the Southern landscape, the physical world of beauty around me, and the social climate. I begin with that. I talked about lynching very early. When I wrote Jubilee, the theme in the book was freedom. I'm talking about freedom from slavery, and freedom from oppression. My poetry continues that theme of getting freedom for our people. I talked about freedom in "For My People"; I talked 
about freedom in "Prophets for a New Day"; I talked about freedom in Jubilee and How I Wrote Jubilee. I attempted to understand what it meant to have social change and its benefits for black people and their rights in the 1930s. I think that I have consistently stayed on that theme.

Now, I don't think that individual freedom and mass revolution can be separate. I think they go together. I said once in an article that I wrote-I think it was on the humanistic tradition in Afro-American literature-that some of us are too old to understand the kind of social change we need in this country, but our children are not too young. We owe them another world; we owe them another mind to face the future. We hope that the 21st century will not be so racist, fascist, and sexist as the 20th century. Black women writers, and particularly myself, have faced three main problems or conflicts in all our work: racism, fascism, and sexism. I think I have been fighting them all my writing career.

Graham: Last question - what other books are there to be written by Margaret Walker?

Alexander: Well, I hope I live to finish about four or five more. I don't know. I write so slowly. I'm trying now to finish my Black-Eyed Susans, which is about Jackson State College, where I worked for 30 years-and where two students were killed in 1970. That incident is the core of the book. I have decided to expand it to show what has happened there on the campus, why violent things could happen, and what we are going through now which tells us it could happen again.

Graham: So it's sort of a fictional text based on social history?

Alexander: That's right. I thought at first that it would be just about 150 pages. Now it looks like it's going to be a longer book because I think you have to go back through the history of the black college to understand how the racist environment started, and what it was like from the beginning.

Graham: Haven't there been any books on the black college experience?

Alexander: Nobody has done the kind of story that shows the conflict in the society as being racist-the conflict between black and white. All black people in the South feel that education for the black man is still a matter of white control, and those whites who control it are not necessarily liberal in their attitudes toward blacks. They are very conservative and fascist. They are very reactionary. And how the black college has lived in that environment is amazing.

Graham: Well, what do you think about the survival of these schools?

Alexander: The ones that will remain will be the ones that were privately founded in the beginning.

Graham: That's interesting. So the state colleges are going to have difficulty?

Alexander: The state colleges are going to strive more and more to become white institutions, because the white citizen doesn't want to pay taxes to educate black people, and we are constantly fighting that. Black people don't have the money to keep their state schools up. I think we're going to lose a lot of them in the deep South. I don't know what their future will be, but we've already seen this happen partially in Missouri, West Virginia, Kentucky, and Texas. The school doesn't have to be a little school or a big school, just a school that's growing and flourishing and very visible.

Graham: So here again, in Black-Eyed Susans, you're taking a piece of the black experience that has heretofore 
not been explored and giving it to us ...

Alexander: Well, I'm also very anxious to have a lot of humor in it. There's a lot of humor, but there's also plenty of gossip. And I don't just talk about the black school, I also talk about the white schools surrounding it, and how some of the same things that are leveled as criticism of the black schools go on at the white ones as well. But they are never out in the news.

Graham: And another book? Your autobiography, perhaps?

Alexander: Well, that autobiography has been waiting more than 25 years, and in the last few years I've learned a great deal about autobiography. I've read two of James Olney's books on autobiography. At one time, it was going to be a book about vision. But then I began to think about Cassandra as I talk about her in Richard Wright. I once said I would think of the book as I Am Cassandra, but I'm very reluctant to use the pronoun I at the beginning of the title. I think I'm going to call it Call Me Cassandra. It emphasizes several things-my feelings of vision, and ritual and ceremony, and some of the myths and legend. It also deals with family history.

Graham: Have you actually started on this book yet?

Alexander: I've been putting down notes and writing outlines and thinking of my life over seven decadeslooking at the first decade, the second, the third, the fourth, the fifth, the sixth. I have a historical feeling for it, but I also would like it to have spatial organization, and not necessarily chronological. I think that's going to be difficult, but I think I'll write it like I would a novel or a poem.

Graham: Will it be a sort of This Is My Century in prose?
Alexander: It'll have images out of the South, because my life's been in the South, but also the experiences at Iowa, Northwestern, and Yale.

Graham: It must please you ever so much to be living, alive and very well, in a period when black Southern literature is really coming into its own in a different kind of way.

Alexander: Well, I think I said this one night when we were talking about Southern literature in the libraries and also said it in the Richard Wright book. Every section of this country has been celebrated in literature: from the time of the Transcendental movement in New England; the Midwest with Hamlin Garland, Sherwood Anderson, Hemingway, Sinclair Lewis, and that group.

There's been a Southern revolution, but it's been of a different kind. I think more than any other part of the country, the South has made a turn. I wouldn't say to the right or to the left, but it's made a definite turn. And it has been so much influenced by the Civil Rights Movement that nobody thinks now of sending out an anthology on the great writers of the Western world without including black writers. And I can't tell you how many black women writers who were never in these books before are now included. It is gratifying to pick up any one of these books in any state in this union and see not only your own work but that of many other black writers that you know. That didn't happen prior to the Civil Rights Movement, and it has continued to happen ever since the Movement.

To kill the Civil Rights Movement was one of the great desires of the conservatives, fascists, and Republicans. But they can't completely destroy it anymore than they can burn all the books. It's like saying they're going to take the vote away from black people; they can't do that now, although they might make it unpleasant, as they did 
before, to participate and become active in seeking political office. The same thing is true in literature. The white people in this country claimed for many years that all American literature was Eurocentric, and since we didn't belong to the Anglo-Saxon tradition, we had no part in such Eurocen- tricity. There are a few people still out there fighting, but basically they're being overwhelmed not just by Afrocentricity but by what they choose to call multi-culturalism, where the Asian-American, Mexican-American, and Black American must all have a seat at the fellowship table, and feast.

Notes 'God Touched My Life is a biography of Sister Thea Bowman of Canton, Mississippi. A wellknown nun and charismatic leader in the Black Catholic religious movement, Sister Thea died of cancer in 1990. Despite Walker's optimistic prediction, God Touched My Life remains in the initial publishing stage.

${ }^{2}$ The Jesse Jackson volume is currently in press at Wayne State University. 